\title{
IMPLEMENTASI METODE CERRY LALALAND DALAM PEMBELAJARAN JARAK JAUH
}

\section{IMPLEMENTATION OF CERRY LALALAND METHOD IN DISTANCE LEARNING}

\author{
Eko Heriyanto $^{1^{*}}$, Bondan Eko Suratno ${ }^{2}$, Adityo Putro Wicaksono ${ }^{3}$ \\ Sastra Inggris, Universitas AKI, Indonesia ${ }^{1,2}$ \\ Teknologi Informasi, Universitas AKI, Indonesia ${ }^{3}$ \\ $\underline{\text { eko.heriyanto@unaki.ac.id }}^{1}$, bondan.eko@unaki.ac.id ${ }^{2}$, $\underline{\text { adityo.putro@unaki.ac.id }}^{3}$ \\ *penulis korespondensi
}

\begin{tabular}{ll}
\hline Info Artikel & ABSTRAK \\
\hline Sejarah artikel: & Penelitian ini bertujuan untuk menjelaskan langkah-langkah implementasi \\
Diterima: & Cerry Lalaland sebagai metode alternatif pembelajaran sastra anak dan \\
14 September 2021 & mengetahui sikap responden terhadap metode tersebut. Metode yang \\
Direvisi: & digunakan dalam penelitian ini adalah deskriptif kualitatif dan kuantitatif. \\
3 Desember 2021 & Pengumpulan data menggunakan kuesioner. Analisis data menggunakan \\
Disetujui: & skala likert. Hasil penelitian ini adalah Cerry Lalaland dilakukan dengan \\
30 Desember 2021 & pengumpulan nursery rhymes dan lagu dolanan Jawa, menganalisis nilai \\
& moral, sejarahnya, pembuatan web, implementasi dalam pembelajaran dan \\
Kata kunci: & pengisian kuesioner. Hasil uji menggunakan skala likert menunjukkan \\
sastra anak, nursery & bahwa metode Cerry Lalaland ini berada dalam kategori "Baik" dengan \\
rhymes, lagu dolanan & indeks prosentase 68,6\%. Dengan demikian, simpulannya adalah bahwa \\
jawa & metode cerry lalaland ini baik untuk diimplementasikan pada pembelajaran \\
& sastra anak dalam pembelajaran jarak jauh.
\end{tabular}

\begin{tabular}{ll}
\hline Article Info & ABSTRACT \\
\hline $\begin{array}{l}\text { Article history: } \\
\text { Received: }\end{array}$ & $\begin{array}{l}\text { This study aimed to describe the implementation stages of Cerry Lalaland } \\
\text { as an alternative method of learning children's literature and to find out the } \\
\text { 14 September 2021 } \\
\text { respondents' agreement to the method. The method used in this research was } \\
\text { Revised: }\end{array}$ \\
$\begin{array}{l}\text { descriptive qualitative and quantitative method. Questionnaire was used to } \\
\text { collect data and analyze them through likert scale. The results were Cerry }\end{array}$ \\
$\begin{array}{ll}\text { Accepted: } & \text { Lalaland was carried out by collecting nursery rhymes and lagu dolanan } \\
\text { 30 December 2021 } & \text { jawa, analyze moral and historical values, create web, implementate in } \\
& \text { learning and filling out questionnaires. The test results by using the likert } \\
\text { Keale showed that the Cerry Lalaland method was in the "good" category } \\
\text { children's literature, } \\
\text { nursery rhymes, lagu }\end{array}$ & $\begin{array}{l}\text { with a percentage index of 68.6\%. The conclusion was cerry laland is a good } \\
\text { method to be implemented in distance learning. }\end{array}$
\end{tabular}

Copyright (C) 2022, Stilistika: Jurnal Pendidikan Bahasa dan Sastra DOI: http://dx.doi.org/10.30651/st.v15i1.9868

\section{PENDAHULUAN}

Di akhir tahun 2019 di kota Wuhan, Cina, virus Corona pertama kali ditemukan dan menjadi pandemi global sampai hari ini. Tercatat sudah lebih dari 200 negara terkena pandemi covid-19 termasuk Indonesia yang berada di urutan 24 dunia dan tertinggi 
di asia tenggara dalam angka positif Covid-19. Segala sektor terkena imbas pandemi ini terlebih sektor pendidikan mulai dari tingkat PAUD sampai tingkat universitas. Padahal pendidikan adalah isu krusial dalam suatu negara. Meskipun demikian, pendidikan harus tetap berjalan dan dilaksanakan sebaik mungkin.

Melalui instruksinya, pemerintah melalui Kemendikbud menginstruksikan untuk melaksanakan work from home, teaching from home, learning from home bagi seluruh lapisan masyarakat. Tentunya hal ini tidak menjadi hambatan bagi yang sudah berjibaku dengan teknologi. Tanpa kita sadari, sekarang adalah eranya serba online (daring) termasuk belajar online atau yang sering kita sebut dengan pembelajaran jarak jauh. Memang pembelajaran jarak jauh ini lebih menantang meski masih dilema antara kualitas dan kuantitas bila dibandingkan dengan pembelajaran tatap muka. Namun, di kala pandemi, inilah jalan yang terbaik yang harus diambil dan dilakukan tanpa terkecuali pendidikan bahasa.

Sastra, bahasa, dan budaya merupakan tiga hal yang tidak dapat dipisahakan dan saling berhubungan satu sama lain. Ketiga unsur tersebut merupakan identitas suatu bangsa yang mampu memberikan penekanan karakter yang dimiliki oleh masyarakat (Rondiyah et al., 2017). Budaya suatu masyarakat dapat dipahami melalui sastra. Sastra juga menunjukan makna dan simbol kebangsaan. Karya sastra mampu menggambarkan suatu kondisi peradaban masyarakat saat karya sastra tersebut ditulis. Peradaban yang dimaksud adalah ciriciri, kondisi sosial, adat istiadat masyarakat kala itu (Fuadhiyah, 2011).

Nursery rhymes adalah salah satu bentuk karya sastra dari negara Inggris, sedangkan lagu dolanan Jawa merupakan karya sastra dari Jawa (khususnya Jawa Tengah dan Jawa Timur). Namun, anak-anak kini lebih cenderung ke lagu-lagu pop maupun yang lagi hits saat ini. Terlebih lagu dolanan anak yang sudah mulai ditinggalkan dan dirasa sudah kuno. Oleh karena itu, dibutuhkan strategi yang efektif dan interaktif dalam membumikannya kembali. Apalagi saat ini terjadi wabah pandemi covid-19 dan telah memasuki era industri 4.0 dan internet of things (IoT). Semua serba terkoneksi dengan internet dan bersifat otomatisasi.

Dengan ini, peneliti memberikan satu solusi alternatif pembelajaran sastra anak berbasis interactive web dengan memanfaatkan berbagai fasiltas IoT (internet of things) yang menjadi ciri dari revolusi industri 4.0 yaitu dengan metode Cerry Lalaland. Penelitian ini bertujuan untuk menjelaskan langkah - langkah implementasi Cerry Lalaland sebagai metode alternatif pembelajaran sastra anak dan mengetahui sikap responden terhadap metode tersebut. Selain sebagai bentuk integrasi sastra ke pendidikan, urgensi dari penelitian ini adalah sebagai pelestarian budaya Indonesia yang kaya ini agar tidak lekang oleh waktu dan zaman. Segala sesuatunya memang harus dilakukan sesuai dengan zamannya.

Cerry Lalaland adalah akronim dari Creative and Interactive Web of Nursery Rhymes and Lagu Dolanan Anak Djawa. Ini merupakan metode alternatif pengajaran sastra anak berbasis interactive web pada pelaksanaan pembelajaran jarak jauh. 
Nursery rhymes adalah sebuah puisi atau lagu tradisional berbahasa Inggris yang diajarkan pada anak-anak kecil, khususnya di taman kanak-kanak seperti Brother John, twinkle twinkle little star, baa baa black sheep, dan sebagainya yang biasanya digunakan untuk melatih kemampuan pelafalan dan bermusik anak (Bolduc \& Lefebvre, 2012). Hal ini disebabkan oleh jiwa anak yang memang menyukai bernyanyi apalagi bila rutinitas belajar dirubah pada hal yang berhubungan dengan musik (Pourkalhor \& Tavakoli, 2017). Selain itu, nursery rhymes juga dapat memberikan perkembangan positif bagi emosi dan perilaku anak (Mullen, 2017).

Tembang atau lagu dolanan Jawa adalah lagu untuk anak-anak yang mempunya nilai moral yang tinggi dan biasanya dinyanyian dengan pelaksanaan suatu permainan. Misalnya, lagu "cublak- cublak suweng". Anak-anak menyanyikan lagi ini sembari mengundi koin atau batu di atas punggung anak yang terkena giliran. Tak elak, masa anak-anak dahulu lebih mempunyai jiwa tanggap, tepo seliro, ramah dan nilai positif lainnya (Rosmiati, 2014; Hardiyan et al., 2019)

Konten dari Cerry Lalaland adalah hasil analisis moral value dan historical review dari nursery rhymes dan lagu dolanan dengan menggunakan teori reader response. Teori ini memberikan pemahaman tersendiri bagi pembaca pada teks yang dibaca serta menghasilkan intepretasi yang digunakan oleh pembaca berdasarkan analisisnya (Trisnawati, 2009).

Di sisi lain, inovasi pendidikan melalui teknologi merupakan sebuah keniscayaan. Tidaklah berarti apa-apa bila pembelajaran jarak jauh tanpa didukung sarana teknologi masa kini, yaitu teknologi otomatisasi dan teknologi siber. Keduanya merupakan ciri dari revolusi industry 4.0 yang digagas oleh Schwab (2016). Inovasi merupakan kunci eksistensi dari berbagai lini saat ini termasuk inovasi pendidikan (pengajaran dan pembelajaran) berbasis teknologi seperti web-based learning, LMS, dan lain-lain.

Web-based learning yang berarti pembelajaran berbasis web menjadi salah satu inovasi dalam bidang pendidikan. Konten yang diunggah dapat disesuaikan dengan materi pembelajaran dan dapat dibuat komunikasi dua arah. Guru dan siswa dapat berinteraksi langsung, tanya jawab, mengumpulkan ide-ide baru, dan lain-lain secara virtual. Hasil penelitian sebelumnya menyatakan bahwa pembelajaran melalui web juga mampu meningkatkan hasil pembelajaran dan minat serta motivasi peserta didik (Syahruddin \& Pongpalilu, 2014; Priyambodo et al., 2012; Wijaya, 2019)

Dengan adanya masa pandemi yang masih belum usai, maka pembelajaran jarak jauh merupakan salah satu alternatif yang memungkinkan untuk dilaksanakan demi berlangsungnya pembelajaran. Secara umum, pembelajaran daring mampu mengatasi berbagai persoalan, seperti jarak, waktu, biaya, dan terbatasnya sumber daya pengajar (Fuady, 2016). Senada dengan hal tersebut, PJJ merujuk pada kemampuan untuk memberikan pendidikan kapan saja dan di mana saja melalui internet. Meskipun, tidak dilaksanakan dengan tatap muka, PJJ akan mempunyai kualitas yang sama bila menerapkan manajemen sistem kualitas yang baik (Fransiska, 2018). Walaupun demikian, hal ini tidak lepas dari berbagai 
kekurangan tertama sarana dan prasarana.

\section{METODE}

Metode yang digunakan dalam penelitian ini adalah metode deskriptif kualitatif dan kuantitatif. Metode kualitatif ini digunakan untuk mendeskripsikan atau menjelaskan langkah - langkah implementasi Cerry Lalaland. Metode kualitatif merupakan metode yang berfungsi untuk menggambarkan serangkaian suatu kejadian/ peristiwa secara akurat, terstruktur dan terukur (Sugiyarto \& Kusmayadi, 2009; Sudaryanto, 1986). Sedangkan metode kuantitatif digunakan untuk menggambarkan dan menjelaskan sikap responden melalui hasil kuesioner.

Data primer penelitian ini adalah hasil penelitian dalam bentuk jurnal dan buku yang berkaitan topik penelitian, sedangkan data sekunder adalah data lapangan yang berupa dokumentasi dan hasil angketisasi. Analisis data kuesioner dilakukan dengan penggunaan skala likert. Adapun populasi penelitian tersebut berjumlah 100 mahasiswa yang mengambil matakuliah Introduction to Literature.

\section{HASIL DAN PEMBAHASAN Implementasi Metode Cerry Lalaland dalam Pembelajaran Sastra Anak}

Adapun langkah-langkah penerapan metode tersebut adalah

a. Pengumpulan nursery rhymes dan lagu dolanan jawa beserta audionya

Adapun contoh nursery rhymes yang dapat dikumpulkan dalam penelitian ini antara lain: $B a a, B a a$, Black Sheep, Humpty Dumpty, Hickory Dickory Dock, One Two, Jack and Jill, Polly Wolly Doodle, The Wheel on The Bus, Yankee Doodle, Bits of Paper, Teddy Bear Teddy Bear, Pussy-Cat
Pussy-Cat, Hop a Little, A Baby, Ding Dong Bell, My Old Kentucky Home, I've Been Working in the Railroad, This Old Man, Swing Low Sweet Chariot, In And Out the Dusky Blue Bells, My Bonnie Lies Over the Ocean, Michael, Row the Boat Ashore, Red River Valley, The Gingerbread Man, Lazy Mary (Will You Get Up), Old Black Joe, Over In the Meadow, The Mulberry Bush, Silent Night, The Happy Wanderer, Marry Had Little Lamb, Erie Canal, London Bridge Is Falling Down, Old Mac Donald, Twinkle Twinkle Little Star, Are You Sleeping, Two Little Hands To Clap Clap Clap.

Selain itu, contoh dari lagu dolanan Jawa antara lain Lir ilir, Sluku Sluku Bathok, Gundul Gundul Pacul, Dondhong Opo Salak, dan Cublak Cublak Suweng, Padang Mbulan, Jaranan, Gambang Suling, Jamuran, Menthok Menthok, Gajah Gajah, Tikus Buntung, Gotri Legenderi, Bang Bang Tut, Pitik Walik, Kodok Ngorek, Kidang Talun, Kucing Gandhik, Saiki Aku Wis Gedhe, dan Siji Loro Telu.

Dari sekian banyak nursery rhymes dan lagu dolanan anak, maka dipilih beberapa yang mempunyai kemasyhuran di masyarakat baik di kalangan keluarga maupun sekolah (PG PAUD, TK, SD), yaitu: Are You Sleeping Brother John?, London Bridge is Falling Down, Twinkle Twinkle Little Star, Baa Baa Black Sheep, Hickory Dickory Dock, Old MacDonald Had a Farm, Lir ilir, Sluku Sluku Bathok, Gundul Gundul Pacul, Dondhong Opo Salak, dan Cublak Cublak Suweng.

b. Analisis nilai moral dan sejarah Nursery Rhymes mempunyai nilai moral dan sejarah tersendiri dibalik bait-bait lagunya. Ada yang berupa satire, nasihat, protes, etika dan 
lain lain (Green, 2007; Kelsy, 2016; Bright, 2019) . Berikut adalah nilai moral dan sejarah nursery rhymes

\author{
Are you sleeping? \\ Are you sleeping? \\ Brother John, Brother John \\ Morning Bells are ringing \\ Morning Bells are ringing \\ Ding dang dong \\ Ding dang dong
}

Lagu tersebut adalah sajak anakanak asal Prancis di abad ke-13. Judul aslinya adalah "Frère Jacques" yang mempunyai arti yang sama dengan brother John dalam bahasa Inggris. Lagu ini berkisah tentang seorang biarawan bernama Jacques yang ketiduran saat bertugas dan didesak untuk bangun dan membunyikan bel gereja untuk melaksanakan matin (doa tengah malam atau pagi-pagi sekali dimana seorang biarawan diharapkan untuk bangun). Melihat dia ketiduran, seseorang membangunkannya dengan lagu ini. Nilai moral yang dapat diambil adalah laksanakanlah tugas dan tanggungjawab dengan sebaik-baiknya (kredibel) terlebih di pagi hari apalagi berkaitan dengan ibadah.

\section{London Bridge is falling down Falling down, falling down London Bridge is falling down My fair lady Build it up with iron bars Iron bars, iron bars Build it up with iron bars My fair lady \\ Iron bars will bend and break \\ Bend and break, bend and break \\ Iron bars will bend and break My fair lady}

Nursery rhymes tersebut sering dilantunkan dalam sebuah permainan dengan berbagai jenis dan tipe. Lagu ini berlatar belakang usaha penghancuran Jembatan London dan upaya perbaikannya yang sangat fantastis.
Sajak lagu ini sudah ditemukan pada abad ke-17. Pada pertengahan abad ke18, liriknya pertama kali dicetak dengan gaya modern, dan seabad kemudian menjadi lagu yang terkenal di daratan Inggris dan Amerika. Lagu tersebut menjadi lagu yang paling terkenal di penjuru dunia dan telah dijadikan sebagai referensi dalam berbagai karya sastra dan budaya populer. Nilai moral yang terkandung dalam lagu ini adalah pantang menyerah dalam hidup dan segera bangkit setelah jatuh hancur.

Twinkle, twinkle, little star

How I wonder what you are

Up above the world so high

Like a diamond in the sky

Twinkle, twinkle little star

How I wonder what you are

Lagu tersebut diciptakan oleh Jane Taylor pada abad ke-19 dan dikenal sebagai lagu pengantar tidur anak. Lagu ini juga pernah diaransemen oleh beberapa komposer termasuk Mozart. Pada tahun 1806, lirik lagu ini pertama kali terbit berjudul "The Star" di Rhymes for Nursery yang digagas oleh Jane Taylor dan Ann Taylor di London. Nilai moral yang terkandung adalah raihlah cita-cita setinggi bintang di langit agar menjadi manusia yang berharga seperti batu permata. Jangan pernah takut bermimpi. Jadikan mimpi itu menjadi kenyataan.

$$
\begin{gathered}
\text { Baa, baa, black sheep } \\
\text { Have you any wool? } \\
\text { Yes sir, yes sir } \\
\text { Three bags full } \\
\text { One for the master } \\
\text { One for the dame } \\
\text { And one for the little boy } \\
\text { Who lives down the lane }
\end{gathered}
$$

Lagu ini benar-benar mengisahkan apa yang terjadi pada perekonomian Inggris saat itu. Betapa 
pentingnya domba dengan bulu wolnya. Wol menjadi komoditas penting tahun 1500-an. Meskipun demikian, para gembala domba tidak menikmati hasil gembalanya dengan maksimal karena pemberlakuan pajak oleh pemerintah. Nilai moralnya adalah berbagilah dengan sesama untuk hidup yang lebih baik. Tidak boleh menindas/ menzalimi minoritas/ orang kecil. Perlakukan mereka sesuai dengan haknya.

Hickory, dickory, dock,

The mouse ran up the clock.

The clock struck one,

The mouse ran down,

Hickory, dickory, dock

Nursery rhymes ini pertama kali diterbitkan pada tahun $1744 \mathrm{~d}$ Amerika Serikat. Lagu ini mengisahkan tentang pemimpin militer dan politikus Inggris, Oliver Cromwell, yang menentang monarki. Namun sayangnya, dia tidak punya kuasa lebih untuk mengubah monarki tersebut. Nilai moralnya adalah kita harus pandai-pandai mengukur kemampuan dan kapasitas diri sendiri.

Old MacDonald had a farm, E-I-E-I-O

And on that farm he had a cow, E-I-E-I-O

With a moo-moo here and a moo-moo there Here a moo

There a moo

Everywhere moo-moo

Old MacDonald had a farm, E-I-E-I-O

Old MacDonald had a farm, E-I-E-I-O

And on that farm he had a pig, E-I-E-I-O

With an oink-oink here and an oink-oink there Here an oink

There an oink

Everywhere oink-oink

Old MacDonald had a farm, E-I-E-I-O

Old MacDonald had a farm, E-I-E-I-O

And on that farm he had a duck, E-I-E-I-O

With a quack-quack here and a quack-quack there

Here a quack

There a quack
Everywhere quack-quack

Old MacDonald had a farm, E-I-E-I-O

Old MacDonald had a farm, E-I-E-I-O

And on his farm he had a lamb, E-I-E-I-O

With a baa-baa here and a baa-baa there

Here a baa

There a baa

Everywhere a baa-baa

Old MacDonald had a farm, E-I-E-I-O

Lagu ini ditulis oleh Thomas D'Urfey yang diperuntukan dalam sebuah opera pada tahun 1706. Di kepulauan Inggris dan Amerika Utara, selama ratusan tahun sebelumnya belum pernah punya lagu rakyat. Akhirnya di abad ke-20, lagu tersebut dibakukan dengan memiliki Roud Folk Song Index Nomor 745. Nilai moral dari lagu ini adalah hidup itu harus dinikmati dengan senang gembira dalam situasi dan kondisi apapun.

Begitu juga tembang/ lagu dolanan jawa yang mempunyai nilai moral terutama nasehat hidup dan sejarahnya tersendiri. Sejarah tersebut berkaitan dengan situasi dan kondisi masyarakat pada masa itu (Wahid \& Saddhono, 2017; Hidayah, 2017; Ariesta, 2019; Dewi et al., 2019).

\section{Lir ilir lir ilir tandure wong sumilir Tak ijo royo royo \\ Tak sengguh panganten anyar}

Cah angon cah angon penekno blimbing kuwi Lunyu lunyu penekno kanggo mbasuh dodotiro Dodotiro dodotiro kumintir bedah ing pinggir Dondomana jrumatano kanggo seba mengko sore Mumpung padang rembulane Mumpung jembar kalangane yo surako surak hore

Tembang ini diciptakan oleh $\mathrm{R}$. Syahid yang terkenal dengan Sunan Kalijaga pada awal abad ke-16 saat mulai runtuhnya kerajaan Majapahit dan Islam mulai banyak dianut oleh para adipati. Salah satu cara yang unik yang dijalankan oleh R. Syahid dalam mengenalkan, mengajarkan dan 
mengamalkan islam tanpa menghilangkan tradisi yang sudah lama berkembang di masyarakat yaitu melalui tembang yang penuh makna dan nilai moral. Nilai moral yang terkandung antara lain membanyak perbuatan baik, menyiapkan bekal sesudah mati, menggunakan kesempatan sebaik-baiknya untuk beribadah kepada Tuhan YME.

Sluku-sluku batok, batok'e ela-elo

Si Rama menyang solo, oleh-olehe payung mutha

Mak jenthit lolo loba, wong mati ora obah yen obah medeni bocah, yen urip golekno duit

Tembang Jawa Sluku-Sluku Bathok ini ditulis oleh R. Syahid juga dengan tujuan dan implementasi yang sama yaitu membuat tembang untuk syiar islam agar mudah dipahami masyarakat awam saat itu. Tembang tersebut dinyanyikan bersamaan dengan sebuah permainan oleh anakanak. Mereka senang melantunkan tembang ini sambil bermain tanpa tahu makna yang terkandung pada liriknya. Adapun nilai moral yang terkandung adalah carilah harta sewajarnya saja sebagai bekal hidup di dunia dengan memperhatikan asal muasal dan cara mendapatkannya, hidup yang seimbang dan selalu mendekatkan diri pada Sang Maha Kuasa.

Gundul gundul pacul cul
Gembelengan
Nyunggi nyunggi wakul kul
Gembelengan
Wakul ngglimpang
Segone dadi sak latar
Wakul ngglimpang
Segone dadi sak latar

Tembang jawa Gundul Gundul Pacul ini juga diciptakan oleh R. Syahid pada abad ke-14. Tembang tersebut juga memiliki tujuan dan implementasi yang sama dengan tembang jawa sebelumnya yaitu lebih mengedepankan hegemoni nilai islam dengan tidak merusak budaya masyarakat setempat yang adiluhung. Nilai moral yang dapat diambil adalah bahwa sebagai manusia seyogyanya bisa berempati dengan kondisi sekitarnya, mempunyai kredibilitas sebagai pemimpin, dan tidak boleh menyombongkan diri.

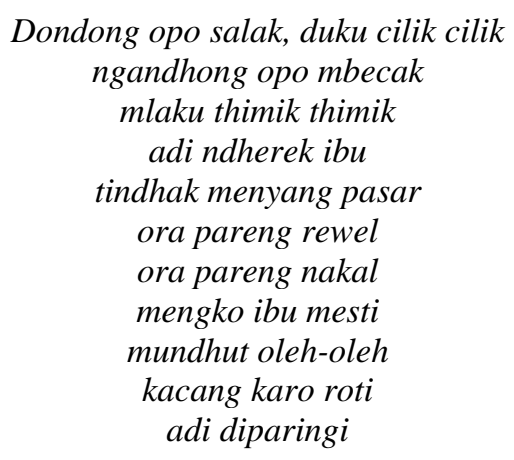

Lagu ini diciptakan oleh seseorang yang multitalenta, Kris Biantoro. Lagu ini sangat populer pada tahun 1960-an sampai 1970-an. Adapun nilai moral yang terkandung adalah di dalam kehidupan pasti dihadapkan dengan berbagai pilihan. Jangan terkecoh dengan tampilan luar. Semua membutuhkan proses tiada yang instan demi hasil yang maksimal.

\section{Cublak-cublak suweng \\ Suwenge teng gelenter Mambu ketundung gudhel \\ Pak Empong lerak-lerek \\ Sopo ngguyu ndelekakhe \\ Sir-sir pong dele kopong \\ Sir-sir pong dele kopong}

Tembang jawa Cublak-cublak Suweng ini diciptakan oleh R. Ainul Yaqin (lebih dikenal sebagai Sunan Giri) pada tahun 1442 M di Jawa Timur. Serupa dengan ulama lainnya, diciptakannya tembang jawa adalah sebagai media syiar dan dakwah agar islam mudah dipahami, dicerna dan diamalkan oleh masyarakat awam 
terlebih anak-anak. Adapaun nilai moral tembang tersebut adalah meraih kemuliaan hidup itu harus selalu mendekatkan diri kepada Sang Maha Kuasa dan bersikap baik kepada sesama terlebih kepada yang membutuhkan.

\section{c. Pembuatan web Cerry Lalaland Pembuatan web dapat} menggunakan hosting yang sederhana, mudah dijalankan, dan mudah dipahami. Cerry Lalaland menggunakan hosting wordpress/ blogspot karena sangat sederhana dan mudah mengoperasikannya. Adapun yang terpajang di web tersebut antara lain: judul, latar belakang, manfaat, nursery rhymes, lagu dolanan jawa, penulis dan kuesioner.

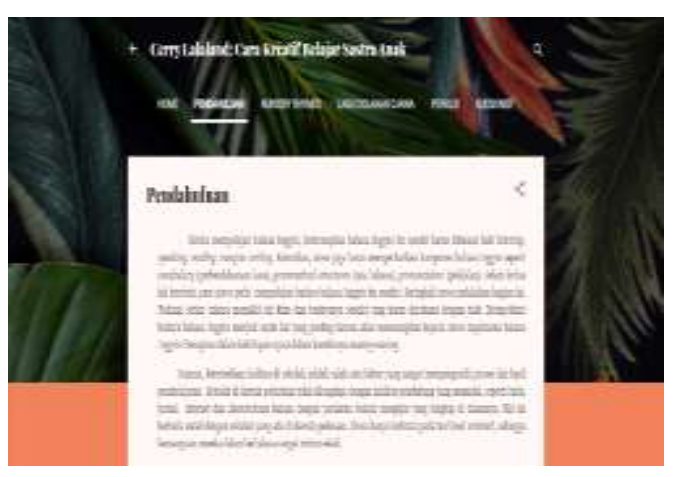

\section{Gambar 1. Tampilan Web Cerry Lalaland}

Pada kolom latak belakang/ pendahuluan dijelaskan mengenai analisis situasi dan kondisi yang terjadi saat ini. Kolom nursery rhymes dan lagu dolanan jawa berisi beberapa judul lagu yang popular sampai saat ini, sejarah dan audionya. Kolom penulis berisikan nama-nama yang terlibat dalam pembuatan dan pengimplementasian Cerry Lalaland. Yang terakhir adalah kolom kuesioner yang merupakan aspek interaktif dalam pembelajaran menggunakan metode
Cerry Lalaland sebagai wujud timbal balik.

d. Implementasi metode Cerry Lalaland dalam pembelajaran sastra anak

Metode tersebut diimplementasikan dalam mata ajar introduction to literature di semester II program studi Sastra Inggris Universitas AKI pada bahasan Sastra Anak. Mula-mula pengajar memberikan pengantar terlebih dahulu seperti yang ada di kolom latar belakang. Kemudian pengajar melanjutkan ke kolom nursery rhymes dan lagu dolanan Jawa dengan model diskusi kelompok. Di sini, peserta melakukan eksplorasi mengenai karya sastra anak dengan mandiri apakah mereka mengetahui seluk-beluk dari karya sastra anak tersebut atau tidak. Indikator pencapaian hasil belajar peserta adalah mereka mengerti memahami, menjelaskan serta mampu menyanyikan lagu-lagu tersebut dengan baik dan benar. Setelah itu, mereka mengisi kuesioner sesuai dengan kondisi pemahaman mereka masing-masing.

Pembelajaran tersebut sangat bermanfaat untuk diterapkan secara daring (pembelajaran jarak jauh/ PJJ) selama kurang lebih 2-3 kali pertemuan. Kemudahan akses dan pemanfaatan teknologi cloud (awan) yang semakin canggih dapat memberikan model pembelajaran alternatif yang solutif dan kreatif.

\section{e. Pengisian kuesioner}

Tahapan ini adalah tahapan terakhir sebagai wujud timbal balik pembelajaran. Peserta mengisi kuesioner secara daring dengan memanfaatkan platform google form sesusai dengan kondisi pemahaman masing-masing. Kuesioner tersebut 
menggunakan alur yang sederhana dengan penilaian berupa angka yang berfokus pada pembelajaran sastra anak melalui metode Cerry Lalaland.

\section{Hasil Analisis Kuesioner}

Dari data yang masuk, ada sejumlah 100 responden yang mengisi kuesioner tentang respon mereka terhadap Cerry Lalaland sebagai metode pembelajaran sastra anak yang informatif, kreatif dan interaktif. Kemudian data tersebut dianalisis menggunakan skala likert.

Adapun hasil rekapitulasi kuesioner adalah sebagai berikut: Sangat Setuju (23), Setuju (32), Raguragu (20), Tidak Setuju (15), dan Sangat Tidak Setuju (10).

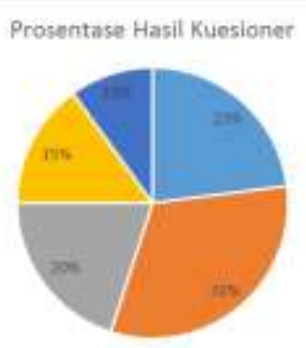

Diagram 1: Persentase Hasil Kuesioner

Dengan menggunakan rentang nilai 1-5, maka total skor penilaian responden yang diperoleh adalah 343 dengan nilai maksimal (Y) adalah 500 . Adapun indeks prosentase yang diperoleh adalah $68,6 \%$ dengan menggunakan rumus:

Indeks $\%=\underline{\text { Total skor } x 100}$

Untuk mengetahui posisi indeks persentase, maka harus ditentukan terlebih dahulu interval (rentan jarak) dan interpretasi persentase dengan menggunakan metode mencari interval skor persentase (I) dengan rumus:

$$
I=100 / \text { Jumlah skor (likert) }
$$

Maka, I $=100 / 5=20$.

Sehingga pengukuran interpretasi skor di atas, diperoleh hasil berdasarkan nilai interval adalah sebagai berikut:

Tabel 1. Interpretasi Interval Skor Persentase

\begin{tabular}{|l|l|l|}
\hline No. & Nilai I & Interpretasi \\
\hline 1 & $0 \%-19,99 \%$ & $\begin{array}{l}\text { Sangat (tidak } \\
\text { setuju/ buruk/ } \\
\text { kurang sekali) }\end{array}$ \\
\hline 2 & $20 \%-39,99 \%$ & $\begin{array}{l}\text { Tidak Setuju/ } \\
\text { Kurang Baik }\end{array}$ \\
\hline 3 & $40 \%-59,99 \%$ & Cukup/ Netral \\
\hline 4 & $60 \%-79,99 \%$ & Setuju/ Baik/ Suka \\
\hline 5 & $80 \%-100 \%$ & $\begin{array}{l}\text { Sangat (Setuju/ } \\
\text { Baik/ Suka) }\end{array}$ \\
\hline
\end{tabular}

Dengan demikian, berdasarkan hasil analisis kuesioner menggunakan skala likert, responden memilih "setuju" bahwa Cerry Lalaland adalah metode pembelajaran sastra anak yang informatif, kreatif dan interaktif. Dengan kata lain, indeks prosentase yang diperoleh yakni $68,6 \%$ menunjukkan bahwa Cerry Lalaland ini berada dalam kategori "Baik".

\section{PENUTUP}

Implementasi metode Cerry Lalaland ini dilakukan dengan pengumpulan nursery rhymes dan lagu dolanan jawa, menganalisis nilai moral dan sejarahnya, pembuatan web, implementasi dalam pembelajaran dan pengisian kuesioner. Pembelajaran membutuhkan ide-ide kreatif dengan banyak pemanfaatan dan pengintegrasian dengan kemajuan teknologi saat ini. Berdasarkan analisis Skala Likert, diperoleh indeks prosentase $68,6 \%$ yang berarti bahwa metode Cerry Lalaland berada dalam kategori "baik" dalam implementasi pembelajaran sastra anak dengan 
pemanfaatan teknologi informasi (ICT).

\section{DAFTAR PUSTAKA}

Ariesta, F. W. (2019). Nilai Moral Dalam Lirik Dolanan CublakCublak Suweng. Ilmu Budaya Cakrawala, 7(2), 188-192. http://journal.unhas.ac.id/index.ph p/jib/article/view/7104.

Bolduc, J., \& Lefebvre, P. (2012). Using Nursery Rhymes to Foster Phonological and Musical Processing Skills in Kindergarteners. Creative Education, 03(04), 495-502. https://doi.org/10.4236/ce.2012.3 4075.

Bright, F. O. (2019). MORAL VALUES AND MULTIMODALITY IN SELECTED REWORKED ANIMATED NURSERY RHYMES FROM CHU CHU TV , $\mathrm{S}$ YOUTUBE CHANNEL. Pristine, 15(1), 138-152. https://www.globalacademicgrou p.com/journals/pristine/MORAL VALUES AND MULTIMODALITY IN SELECTED REWORKED ANIMATED NURSERY RHYMES FROM CHU CHU TV'S YOUTUBE CHANNEL.pdf.

Dewi, T. P., Purwadi, \& Mudzanatun. (2019). Analisis Nilai Karakter Religius dan Nilai Karakter Tanggung Jawab Pada Tembang Dolanan Lir-ilir dan Sluku-Sluku Bathok. SEMAR (Jurnal Ilmu Pengetahuan, Teknologi, Dan Seni Bagi Masyarakat), 8(1), 4449. https://doi.org/10.20961/semar.v8 i1.18044.

Fransiska, R. (2018). Implementasi Total Quality Management pada Pendidikan Jarak Jauh. $A L$ ULUM : Jurnal Ilmu Sosial Dan Humaniora, https://doi.org/10.31602/alsh.v3i2 .1197.

Fuadhiyah, U. (2011). Simbol Dan Makna Kebangsaan Dalam Lirik Lagu-Lagu Dolanan Di Jawa Tengah Dan Implementasinya Dalam Dunia Pendidikan. Lingua, 7(1), 15-26.

Fuady, M. J. (2016). PENGEMBANGAN APLIKASI EVALUASI PEMBELAJARAN ONLINE UNTUK PENDIDIKAN JARAK JAUH. Tekno, 26(September), 148-154. http://journal.um.ac.id/index.php/t ekno/article/view/8281/3812.

Green, P. B. (2007). A History of Nursery Rhymes. Singing Tree Press.

Hardiyan, R. C., Aesijah, S., \& Suharto. (2019). Pembelajaran Lagu Dolanan Untuk menanamkan Nilai Karakter Pada Siswa SD Negeri Sekaran 01. Jurnal Seni Musik, 8(2), 105-115. https://journal.unnes.ac.id/sju/ind ex.php/jsm/article/view/35048.

Hidayah, A. (2017). Makna Budaya Lagu Dolanan: Dhondhong Apa Salak, Gundhul Pacul. Jurnal Penelitian Humaniora, 18(1), 1926. https://doi.org/10.23917/humanio ra.v18i1.3637. 
Kelsy, A. (2016). Nursery Rhymes and the History Behind them. Motifs: An International Journal of English Studies, 2(1), 7-27. https://doi.org/10.5958/24541753.2016.00002.7.

Mayasari, G. H. (2016). Meneropong Teori Sastra Bandingan Pada Buku Metodologi Penelitian Sastra Bandingan. METASASTRA: Jurnal Penelitian Sastra, 4(2), 208.

https://doi.org/10.26610/metasastr a.2011.v4i2.208-2011.

Mullen, G. (2017). More Than Words: Using Nursery Rhymes and Songs to Support Domains of Child Development. Journal of Childhood Studies, 42(2), 42. https://doi.org/10.18357/jcs.v42i2 .17841 .

Pourkalhor, O., \& Tavakoli, M. A. (2017). Nursery Rhymes and Language Learning: Issues and Pedagogical Implications. International Journal of English Language \& Translation Studies, 05(01), 111-116. http://www.eltsjournal.org/archiv e/value5 issue1/14-5-1-17.pdf.

Priyambodo, E., Wiyarsi, A., \& Permana, S. L. (2012). Pengaruh Media Pembelajaran Interaktif Berbasis Web Terhadap Motivasi Belajar Mahasiswa. Jurnal Kependidikan, 42(2), 99-109. https://doi.org/10.21831/jk.v42i2. 2236.

Rondiyah, A. A., Wardani, N. E., \& Saddhono, K. (2017). Pembeljaran Sastra Melalui Bahasa dan Budaya
Untuk Meningktkan Pendidikan Karakter Kebangsaan Di Era MEA (Masyrakat Ekonomi ASEAN). The 1st Education and Language International Conference Proceedings Center for International Language Development of Unissula, 1(1), 141-147.

http://jurnal.unissula.ac.id/index.p hp/ELIC/article/view/1230.

Rosmiati, A. (2014). Teknik Stimulasi dalam Pendidikan Karakter Anak Usia Dini melalui Lirik Lagu Dolanan. Resital: Jurnal Seni Pertunjukan, 15(1), 71-82. https://doi.org/10.24821/resital.v1 $5 \mathrm{i} 1.801$

Schwab, K. (2016). The Fourth Industrial Revolution. World Economic Forum.

Sudaryanto. (1986). Metode Lingusitik. Gadjah Mada University Press.

Sugiyarto, E., \& Kusmayadi. (2009). Metodologi Penelitian Dalam Bidang Kepariwisataan (1st ed.). Gramedia Pustaka Utama.

Syahruddin, \& Pongpalilu, F. (2014). Inovasi Pembelajaran Menulis Kreatif Melalui Web-Based Learning. Jurnal Pendidikan Dan Pembelajaran (JPP), 21(2), 146154.

https://media.neliti.com/media/pu blications/138963-ID-inovasipembelajaran-menulis-kreatifmel.pdf.

Trisnawati, R. K. (2009). Implementing Reader-Response Theory: An Alternative Way of Teaching Literature Research Report on the 
Reading of Booker $\mathrm{T}$ Washington's Up from Slavery*. Journal of English and Education, 3(1), 1-14. https://doi.org/10.20885/jee.vol3.i ss1.art1.

Wahid, A. N., \& Saddhono, K. (2017). Ajaran Moral Dalam Lirik Lagu Dolanan Anak. MUDRA Jurnal Seni Budaya, 32(2), 172-177. https://jurnal.isi- dps.ac.id/index.php/mudra/article/ view/107/50.

Wijaya, M. C. (2019). The Impact of Using Multimedia Interactive Based for Learning Media on Teacher and Student Communication in Bandung. Journal Pekommas, 4(1), 53-60. https://doi.org/10.30818/jpkm.20 19.2040106 